\title{
Clinical and imaging findings of patients diagnosed with adenovirus-positive pneumonia during 2015-2019 in Shanghai, China
}

\author{
Chunrong HUANG ${ }^{1,2, \dagger}$ (D), Dong WEI ${ }^{3, \dagger}$ (D), Yahui $\mathrm{LIU}^{1,2}$ (D), Guochao SHI ${ }^{1,2, *}$ (D) \\ ${ }^{1}$ Department of Pulmonary and Critical Care Medicine, Ruijin Hospital, Shanghai Jiao Tong University School of Medicine, Shanghai, \\ People's Republic of China \\ ${ }^{2}$ Institute of Respiratory Diseases, Shanghai Jiao Tong University School of Medicine, Shanghai, People’s Republic of China \\ ${ }^{3}$ Research Laboratory of Clinical Virology, Ruijin Hospital, Shanghai Jiaotong University School of Medicine, Shanghai, People’s \\ Republic of China
}

Received: $13.10 .2020 \quad \bullet \quad$ Accepted/Published Online: $30.10 .2021 \quad \bullet \quad$ Final Version: 14.04 .2022

Background/aim: This study was to describe the clinical characteristics, chest CT image findings, and potential role of T cells immunity in adenovirus positive pneumonia.

Materials/methods: In this retrospective study, medical records of 53 adult Adv+ patients who were admitted to the Ruijin Hospital, Shanghai Jiao Tong University School of Medicine, from May 2015 to August 2019 were included. The presence of adenovirus and other respiratory viruses was detected using polymerase chain reaction of throat swabs samples. Clinical features and chest computed tomography (CT) findings were compared between patients with Adv+ pneumonia and Adv+ non-pneumonia.

Results: The top 3 most commonly occurring symptoms in Adv+ pneumonia patients were fever (66.7\%), cough (63.3\%), and tachypnea (16.7\%). Patients with Adv+ pneumonia showed significantly higher rates of cough and fever and longer duration of hospitalization than patients with Adv+ non-pneumonia. In the Adv+ pneumonia group, consolidation (73.3\%) was the most common imaging finding on chest CT scan, and the likelihood of involvement of bilateral lobes (60\%) was high. Classical conspicuous consolidation with surrounding ground-glass opacity was observed in 5 (16.6\%) patients with Adv+ pneumonia. Patients with Adv+ pneumonia showed a higher inhibition of T-cell immunity than did patients with Adv+ non-pneumonia, and counts of CD3 $3^{+}, \mathrm{CD}^{+}$, and CD8 ${ }^{+} \mathrm{T}$-cells may predict the presence of pneumonia in $\mathrm{Adv}+$ patients.

Conclusion: With regard to $\mathrm{Adv}+$ pneumonia, the most frequent symptoms were cough and fever, and the most common CT pattern was consolidation; classical CT findings such as consolidation with surrounding ground-glass opacity could also be observed. Furthermore, our data indicated the incidence of abrogated cellular immunity in patients with Adv+ pneumonia.

Key words: Adenovirus, pneumonia, chest CT scan, T cells

\section{Introduction}

Adenovirus (Adv), a non-enveloped double-stranded DNA virus, is quite a common contagious pathogen that causes upper or lower respiratory tract infections in neonates, children, and adults, especially in those with compromised immunity, such as HIV-positive individuals or patients who have undergone transplantation [1-3]. In immunocompetent subjects, adenovirus generally causes mild infections, which are usually self-limiting; however, the incidence of severe pneumonia or acute respiratory distress syndrome (ARDS), for which virulence of newly emergent adenovirus, immune incompetence, or irregulated host immune responses may serve as underlying mechanisms, has also been reported in some studies.

\footnotetext{
*Correspondence: shiguochao@hotmail.com

${ }^{\dagger}$ Authors contributed equally
}

In recent decades, partly owing to several outbreaks of adenovirus infections, such as pneumonia and ARDS, among military personnel in China, South Korea, and the United States [4-7], adenovirus-associated pneumonia has increasingly attracted the attention of researchers. Using whole-genome sequencing, prior studies identified more than 80 serotypes and suggested potential roles of some specific serotypes in different diseases and settings [8]. For instance, serotypes Adv-3, 7, 14, and 55 are implicated in acute respiratory disease [8-12], and Adv-7 and 55 could cause severe pneumonia $[13,14]$.

Generally, doctors rely on clinical manifestations and chest computed tomography (CT) to diagnose adenovirusassociated pneumonia. The clinical and radiological 
features associated with this disease are nonspecific, that is, cough, fever, rhinorrhea, and dyspnea were the most common respiratory symptoms $[15,16]$. Laboratory examinations conducted in some studies indicated the presence of a relative lymphopenia and suppression of T-cell immunity in patients with adenovirus pneumonia, as demonstrated by low levels of $\mathrm{CD}^{+}, \mathrm{CD}^{+}, \mathrm{CD}^{+}$, and $\mathrm{CD}_{2} 0^{+}$T-cells $[1,12,17]$. Adenovirus-associated pneumonia could be represented by imaging findings such as consolidation, ground-glass opacity, pleural effusion, septal thickening, and nodules $[17,18]$, which are not specific enough to distinguish it from bacterial pneumonia.

Therefore, we aimed to compare clinical and imaging evidence between patients with adenovirus-positive $(\mathrm{Adv}+)$ pneumonia and $\mathrm{Adv}+$ non-pneumonia and to investigate the association between cellular immunity and $\mathrm{Adv}+$ pneumonia.

\section{Materials and methods}

\subsection{Subjects}

We retrospectively recruited 53 adult $\mathrm{Adv}+$ patients who were admitted to Ruijin Hospital, Shanghai Jiao Tong University School of Medicine, from May 2015 to August 2019; among them, 30 and 23 patients had Adv+ pneumonia and Adv+ non-pneumonia, respectively.

The combination of the following 3 criteria was used to diagnose Adv+ pneumonia: (1) presence of respiratory symptoms (fever, cough, sputum, dyspnea, etc.), (2) presence of pulmonary infiltrates, consolidation, or ground-glass opacities on CT images, and (3) isolation of Adv from throat swabs. Adv+ non-pneumonia was defined by the isolation of $\mathrm{Adv}$ from throat swabs $(\mathrm{Adv}+)$, with no imaging evidence of respiratory symptoms and pneumonia. Viral co-infection was defined as positivity for two or more types of viruses in any combination. Bacterial co-infection was defined as positivity of other specimens (e.g., sputum, blood) for any kind of bacteria in combination with positivity for adenovirus.

Severe community-acquired pneumonia (CAP) was diagnosed according to the modified American Thoracic Society criteria $[19,20]$. Patients with shock requiring vasopressor therapy or mechanical ventilation or those fulfilling at least 3 of the following criteria were diagnosed with CAP: respiratory rate $>30$ breaths/min at admission, $\mathrm{PaO}_{2} / \mathrm{FiO}_{2} \leq 250$, bilateral or multi-lobar involvement, white blood cell count $\leq 4000$ cells $/ \mathrm{mm}^{3}$, blood urea nitrogen level $\geq 20 \mathrm{mg} / \mathrm{dL}$, core temperature $<36^{\circ} \mathrm{C}$, and hypotension with a need for aggressive fluid resuscitation.

The study was approved by the Ethics Committee of Ruijin Hospital, Shanghai Jiao Tong University School of Medicine.

\subsection{Data collection}

The following data were retrieved from the medical records of the subjects: demographic data (age, year, and duration of hospitalization), symptoms (fever, headache, cough, sputum, sore throat, tachypnea, chest pain, and chest tightness), underlying conditions (lung cancer, asthma, chronic obstructive pulmonary disease [COPD], pleural effusion, hypertension, hypoproteinemia, hepatic dysfunction, chronic kidney disease, glomerulonephritis, diabetes mellitus, and anti-neutrophil cytoplasmic antibodies [ANCA]-associated small vessel vasculitis), the use of immunosuppressive agents, CT findings, and laboratory examination results. The lymphocyte subset measurements were performed by flow Cytometry one day before or after the detection of adenovirus.

\subsection{Detection of adenovirus and other pathogens}

All throat swabs were examined for the presence of adenovirus and other respiratory viruses using multiplex real-time PCR. We screened for adenovirus, influenza A virus, influenza $B$ virus, metapneumovirus, parainfluenza virus, rhinovirus, coronavirus, respiratory syncytial virus, bocavirus, and enterovirus. Nucleic acids were extracted using QiampMinelute Virus Spin Kit (Qiagen, Hilden, Germany). cDNA was synthesized and subjected to multiplex PCR using a respiratory virus 15 -combination multiple PCR kit (Neuro-Hemin Biotech Co, Ltd, Hangzhou, China). An ABI 7500 (Applied Biosystems, California, USA) instrument was used to detect the viruses. The PCR reaction mixture contained $3 \mu \mathrm{L}$ cDNA templates, $4 \mu \mathrm{L} 5 \times \mathrm{RV}$ Primer, $3 \mu \mathrm{L}$ 8-Mop Solution, and $10 \mu \mathrm{L} 2 \times$ multiplex master mix. The reaction mixture was subjected to the following steps: denaturation, $94^{\circ} \mathrm{C}$ for 15 min; amplification, 40 cycles of PCR, $30 \mathrm{~s}$ at $94^{\circ} \mathrm{C}, 90 \mathrm{~s}$ at $60^{\circ} \mathrm{C}$, and $90 \mathrm{~s}$ at $72{ }^{\circ} \mathrm{C}$; and extension, $72^{\circ} \mathrm{C}$ for $10 \mathrm{~min}$. The $2^{\wedge}(-$ Delta Delta $\mathrm{C}(\mathrm{T}))\left(2^{-\Delta \Delta \mathrm{CT}}\right)$ method was used for data analysis [21].

Blood, sputum, and urine samples were cultured to identify bacterial co-infections.

\subsection{Statistical analysis}

Statistical analysis was performed using GraphPad Prism 7 software. Data are shown as means \pm standard deviation (SD) or median (IQR: 1st, 3rd quartiles) for continuous variables, and categorical variables were represented as numbers and percentages (n (\%)). Data were compared using a two-sample t-test for continuous variables, and by chi-squared or Fisher's exact test for categorical variables. A two-tailed $p$ value $<0.05$ was considered to be significant.

\section{Results}

\subsection{Clinical characteristics}

Clinical characteristics of the two groups are summarized in Table 1. Fifty-three patients tested positive for adenovirus, 30 of whom were diagnosed with pneumonia. The mean age of all the patients was $51.11 \pm 21.88$ years, and this study comprised 35 men (66.04\%). Two patients 
HUANG et al. / Turk J Med Sci

Table 1. Clinical characteristics of patients with Adv+ pneumonia and Adv+ non-pneumonia $(\mathrm{n}=53)$.

\begin{tabular}{|c|c|c|c|c|c|c|}
\hline \multirow{2}{*}{ Variables } & \multirow{2}{*}{ Total $(\mathrm{n}=53)$} & \multirow{2}{*}{$\begin{array}{l}\text { Adv }+ \text { pneumonia } \\
(\mathrm{n}=30)\end{array}$} & \multirow{2}{*}{$\begin{array}{l}\text { Adv+ non-pneumonia } \\
(\mathrm{n}=23)\end{array}$} & \multirow{2}{*}{$P$ value } & \multicolumn{2}{|c|}{ KS normality test } \\
\hline & & & & & $\mathrm{p}$ value $\mathrm{e}^{*}$ & $\mathrm{p}$ value\# \\
\hline Age, year & $51.11 \pm 21.88$ & $46.33 \pm 15.16$ & $60.67 \pm 28.97$ & 0.531 & 0.072 & 0.094 \\
\hline Sex (male) & $35(66.04 \%)$ & $19(63.3 \%)$ & $16(69.6)$ & 0.772 & - & - \\
\hline $\begin{array}{l}\text { Duration of hospitalization (days), } \\
\text { median (IQR) }\end{array}$ & $11(7,23)$ & $16(7,29)$ & $8(6,11.5)$ & 0.029 & 0.0019 & 0.0028 \\
\hline $\begin{array}{l}\text { Time from admission to detection of Adv, } \\
\text { day, median (IQR) }\end{array}$ & $3(2,4)$ & $3(1.25,5.25)$ & $3(2,4.5)$ & 0.62 & $<0.0001$ & 0.0039 \\
\hline \multicolumn{7}{|l|}{ Symptoms } \\
\hline Fever $\left(\geq 38^{\circ} \mathrm{C}\right)$ & $21(39.6 \%)$ & $20(66.7 \%)$ & $1(4.3 \%)$ & $<0.001$ & & \\
\hline Headache & $2(3.8 \%)$ & $1(3.3 \%)$ & $1(4.3 \%)$ & 1 & - & - \\
\hline Cough & $23(43.4 \%)$ & $19(63.3 \%)$ & $4(17.4 \%)$ & 0.001 & - & - \\
\hline Sore throat & $1(1.9 \%)$ & $1(3.3 \%)$ & 0 & 1 & - & - \\
\hline Tachypnea & $5(9.4 \%)$ & $5(16.7 \%)$ & 0 & 0.061 & - & - \\
\hline Chest pain & $1(1.9 \%)$ & $1(3.3 \%)$ & 0 & 1 & - & - \\
\hline Chest tightness & $3(5.7 \%)$ & $2(6.7 \%)$ & $1(4.3 \%)$ & 1 & - & - \\
\hline CAP (\%) & $25(47.2 \%)$ & $25(83.3 \%)$ & - & - & - & - \\
\hline Severe pneumonia & $3(5.7 \%)$ & $3(10 \%)$ & - & - & - & - \\
\hline $\begin{array}{l}\text { Use of immunosuppressive agent } \\
\text { (Corticosteroid) }\end{array}$ & $8(15.1 \%)$ & $2(6.7 \%)$ & $6(26.1 \%)$ & 0.065 & - & - \\
\hline Underlying condition & & & & & - & - \\
\hline Lung cancer & $4(7.5 \%)$ & $1(3.3 \%)$ & $3(13 \%)$ & 0.624 & & \\
\hline Asthma & $3(5.7 \%)$ & $2(6.7 \%)$ & $1(4.3 \%)$ & 1 & - & - \\
\hline COPD & $3(5.7 \%)$ & $2(6.7 \%)$ & $1(4.3 \%)$ & 1 & - & - \\
\hline pleural effusion & $9(17.0)$ & $6(20 \%)$ & $3(13 \%)$ & 0.715 & - & - \\
\hline Hypertension & $23(43.4 \%)$ & $11(36.7 \%)$ & $12(52.2 \%)$ & 0.280 & - & - \\
\hline Hypoproteinemia & $3(5.7 \%)$ & $3(10 \%)$ & 0 & 0.249 & - & - \\
\hline Hepatic dysfunction & $13(24.5 \%)$ & $8(26.7 \%)$ & $5(21.7 \%)$ & 0.749 & - & - \\
\hline Chronic kidney disease & $17(32.1 \%)$ & $3(10 \%)$ & $14(60.9 \%)$ & $<0.001$ & - & - \\
\hline Glomerulonephritis & $6(11.3 \%)$ & $2(6.7 \%)$ & $4(17.4 \%)$ & 0.385 & - & - \\
\hline Diabetes mellitus & $12(22.6 \%)$ & $6(20 \%)$ & $6(26.1 \%)$ & 0.743 & - & - \\
\hline ANCA-associated small vessel vasculitis & $2(3.8 \%)$ & $1(3.3 \%)$ & $1(4.3 \%)$ & 1 & - & - \\
\hline
\end{tabular}

$\mathrm{IQR}=$ interquartile range, $\mathrm{COPD}=$ Chronic Obstructive Pulmonary Disease, $\mathrm{CAP}=\mathrm{Community}$ acquired pneumonia. $\mathrm{P}$ value ${ }^{\star}$ means the $\mathrm{p}$ value of Shapiro-Wilk normality test in Adv+ pneumonia group.

$\mathrm{P}$ value $\mathrm{e}^{\star}$ means the $\mathrm{p}$ value of KS normality test in Adv+ pneumonia group, $\mathrm{P}$ value\# means the p value of KS normality test in Adv+ non-pneumonia group.

Data are shown as mean $\pm \mathrm{SD}$, median (IQR) or number (\%).

with Adv+ pneumonia (6.7\%) and 6 patients with Adv+ non-pneumonia (26.1\%) used immunosuppressive agents. Twenty-five (83.3\%) patients with Adv+ pneumonia had CAP. The duration of hospitalization of patients with Adv+ pneumonia (mean [IQR]: $16[7,29]$ ) tended to be longer than that of patients with $\mathrm{Adv}+$ non-pneumonia $(8[6,11.5])(\mathrm{p}=0.02)$. The top 3 frequent symptoms of Adv+ pneumonia were fever (66.7\%), cough (63.3\%), and tachypnea (16.7\%). Patients with Adv+ pneumonia $(19,63 \%)$ were more likely to have cough and fever than were those with Adv+ non-pneumonia (4, 17.4\%) ( $\mathrm{p}=$ 0.001). Patients with chronic kidney disease were more 
common in the Adv+ non-pneumonia group than in the Adv+ pneumonia group $(14,60.9 \%$ vs. $3,10 \%)(p<0.001)$. There were no significant differences in other clinical characteristics between the two groups ( $p>0.05$ ).

\subsection{Chest CT findings}

Chest CT findings are presented in Table 2. Chest CT findings of patients with $\mathrm{Adv}+$ non-pneumonia were different from those of patients with Adv+ pneumonia (Figures 1a-1e). Most of the patients with Adv + pneumonia were diagnosed with CAP $(25,83.3 \%)$. CT features of the Adv+ pneumonia group were as follows: consolidation, 22 patients (73.3\%); ground-glass opacities, 8 patients (26.7\%); spot shadows, 7 patients (23.3\%); nodular lesions, 5 patients (16.7\%); and pleural effusion, 6 patients $(20 \%)$. Notably, 5 patients (16.7\%) showed classical CT findings (Figure 1): conspicuous consolidation with surrounding ground-glass opacity. The lesions of pneumonia were more likely to involve bilateral lobes $(18,60 \%)$, followed by the right lobe (10,33.3\%) and the left lobe (2, 6.7\%).

\subsection{Laboratory examinations}

Comparative findings of laboratory examinations between the two groups are displayed in Table 3. In patients with Adv+ pneumonia, the white blood cell (WBC) count, neutrophils percentage, and C-reactive protein (CRP) level were $7.1 \pm 3.9 \times 10^{9} / \mathrm{L}, 70.66 \% \pm 13.58 \%$, and 7.92 $(2.25,66.75)$ (mean $[\mathrm{IQR}]) \mathrm{g} / \mathrm{L}$, respectively, and $82.6 \%$ of patients showed a Procalcitonin (PCT) level of $<0.5 \mathrm{ng} /$ $\mathrm{mL}$. Patients with Adv+ pneumonia showed higher levels of blood glucose [mean [IQR], $6.62(5.43,11.05) \mathrm{mmol} / \mathrm{L}$ vs. $4.7(4.22,5.67) \mathrm{mmol} / \mathrm{L}, \mathrm{p}=0.001]$ and lower levels of albumin $(\mathrm{p}=0.037)$ and uric acid $(\mathrm{p}=0.008)$ than did those with Adv+ non-pneumonia. Few patients in both the groups showed evidence of viral or bacterial co-infection. For instance, in Adv+ pneumonia patients $(\mathrm{n}=30), 2$ (6.7\%) patients were co-infected with bacteria (Klebsiella pnuemoniae and Staphylococcus aureus, respectively). In Adv+ non-pneumonia patients $(n=23)$, one patient was co-infected with Klebsiella pnuemoniae, and 3 patients were co-infected with viruses, including Respiratory syncytial virus $(\mathrm{n}=2)$ and influenza B virus $(\mathrm{n}=1)$.

\subsection{White blood cell immunophenotypes}

We also compared the white blood cell immunophenotypes in patients with $\mathrm{Adv}+$ pneumonia $(\mathrm{n}=21)$ and $\mathrm{Adv}+$ non-pneumonia $(\mathrm{n}=16)$ (Table 4). Patients with Adv+ pneumonia showed significantly lower numbers of $\mathrm{CD}^{+}$ $(\mathrm{p}=0.034), \mathrm{CD}^{+}(\mathrm{p}=0.031)$, and CD8 $8^{+} \mathrm{T}$-cells $(\mathrm{p}<0.004)$ than did those with Adv+ non-pneumonia.

We further analyzed the receiver operating characteristic (ROC) curve to analyze the accuracy of the counts of $\mathrm{CD}^{+}, \mathrm{CD}^{+}$, and $\mathrm{CD} 8^{+} \mathrm{T}$-cells for use as a biomarker of pneumonia in $\mathrm{Adv}+$ patients. Areas under the ROC curve for $\mathrm{CD}^{+}, \mathrm{CD}^{+}$, and $\mathrm{CD}^{+}{ }^{+} \mathrm{T}$-cells were 0.8423 (Figure 2a), 0.8482 (Figure 2b), and 0.75 (Figure
Table 2. Characteristics of chest CT findings in patients with Adv+ pneumonia $(n=30)$.

\begin{tabular}{|l|l|}
\hline Characteristics & $\begin{array}{l}\text { Adv+ pneumonia } \\
(\mathrm{n}=30)\end{array}$ \\
\hline Pattern & \\
\hline Consolidation & $22(73.3 \%)$ \\
\hline Ground-glass opacity & $8(26.7 \%)$ \\
\hline Spot shadow & $7(23.3 \%)$ \\
\hline Nodular lesions & $5(16.7 \%)$ \\
\hline Consolidation and ground-glass opacity & $5(16.7 \%)$ \\
\hline Pleural effusion & $6(20 \%)$ \\
\hline Mainly involved lobe & \\
\hline Only left lobe & $2(6.7 \%)$ \\
\hline Only right lobe & $10(33.3 \%)$ \\
\hline Either lower lobe & $12(40 \%)$ \\
\hline Bilateral lobes & $18(60 \%)$ \\
\hline
\end{tabular}

Data are shown as number (\%).

2c), respectively, indicating that counts of $\mathrm{CD} 3+, \mathrm{CD} 4+$, and CD8+ T-cells may be used as predictors of pneumonia in $\mathrm{Adv}+$ patients.

\section{Discussion}

The present retrospective study, which compared the clinical features, image findings, and laboratory results between patients with Adv+ pneumonia and Adv+ non-pneumonia, showed that Adv+ pneumonia was associated with a higher risk of cough and fever, longer duration of hospitalization, higher glucose level, and lower albumin and uric acid levels. Consolidation was the most common imaging chest CT finding of patients with $\mathrm{Adv}+$ pneumonia, who were also revealed to harbor lower numbers of $\mathrm{CD} 3+, \mathrm{CD} 4+$, and CD8+ T-cells.

Adenovirus was initially identified in young military recruits in the United States [22]. Over the following decades, multiple outbreaks of adenovirus-related respiratory illness in different populations shed light on the self-limiting course of adenovirus-induced infections and mild symptoms in a majority of immunocompetent individuals $[23,24]$. The infections that progressed with fatal courses (CAP or ARDS), requiring intensive care and invasive trachea intubation, and resulting in fatal outcomes, have been more commonly reported in immunocompromised patients than in immunocompetent patients [1-3]. In our study, severe Adv+ pneumonia was observed in $3(10 \%)$ immunocompetent patients.

Previous reports have identified the most common symptoms of adenovirus infections in the United 

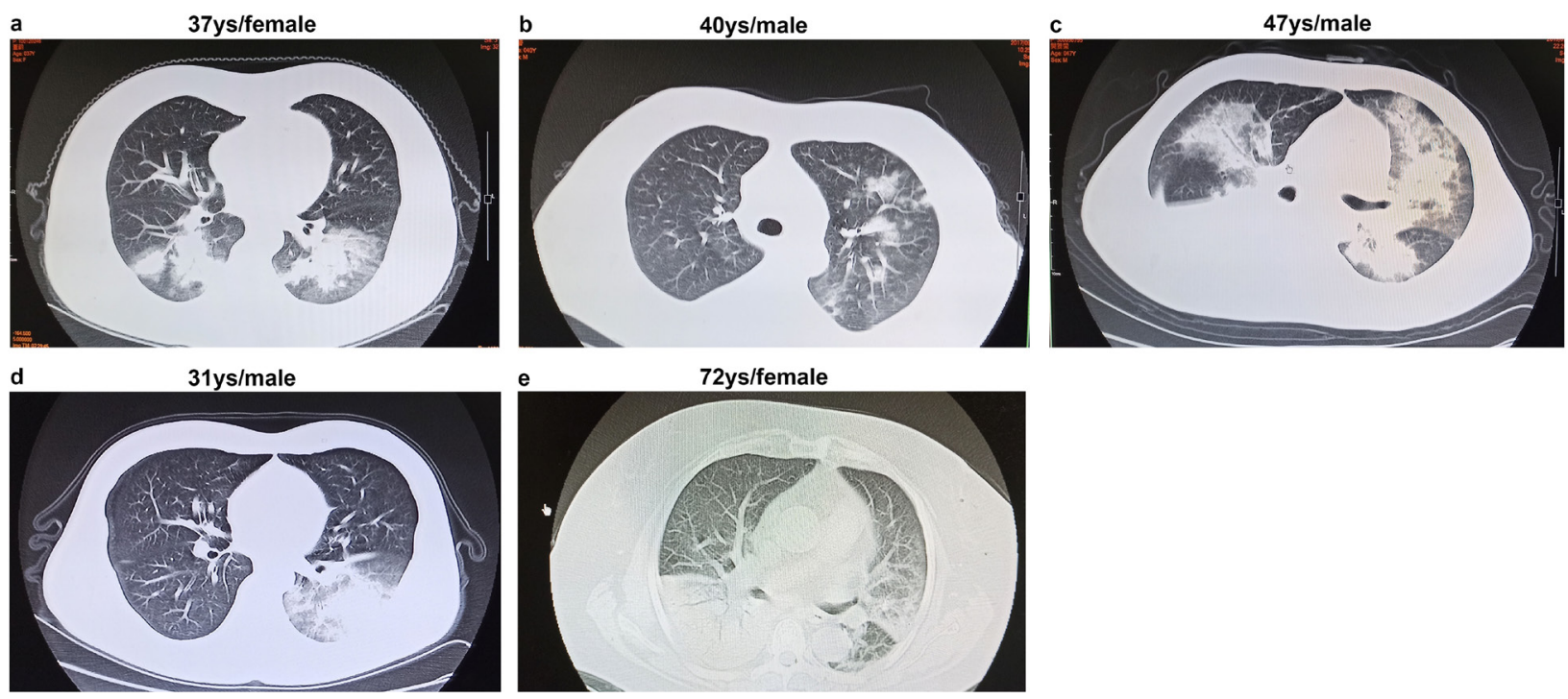

Figure 1. (a-e) Computed tomography images of five patients with adenoviral pneumonia showing consolidation and surrounding ground-grass opacity.

Table 3. Laboratory examinations between patients with Adv+ pneumonia and Adv+ non-pneumonia $(\mathrm{n}=53)$.

\begin{tabular}{|l|l|l|l|l|l|l|}
\hline \multirow{2}{*}{ Laboratory Data } & Total $(\mathrm{n}=53)$ & \multirow{2}{*}{$\begin{array}{l}\text { Adv+ pneumonia } \\
(\mathrm{n}=30)\end{array}$} & $\begin{array}{l}\text { Adv+ non-pneumonia } \\
(\mathrm{n}=23)\end{array}$ & p value & \multicolumn{2}{|l|}{ KS normality test } \\
\cline { 6 - 8 } & & & & & P value* & P value\# \\
\hline WBC, $10^{9} / \mathrm{L}$ & $7.29 \pm 3.22$ & $7.1 \pm 3.9$ & $7.53 \pm 1.96$ & 0.647 & $>0.1$ & $>0.1$ \\
\hline Neutrophil $(\%)$ & $68.32 \pm 11.63$ & $70.66 \pm 13.58$ & $65.27 \pm 7.38$ & 0.098 & $>0.1$ & $>0.1$ \\
\hline Lymphocyte $(\%)$ & $20.96 \pm 10.67$ & $19.65 \pm 12.38$ & $22.66 \pm 7.56$ & 0.318 & $>0.1$ & $>0.1$ \\
\hline CRP $(\mathrm{g} / \mathrm{L})(\mathrm{n}=44)$, median $(\mathrm{IQR})$ & $7.39(1.34,44)$ & $7.92(2.25,66.75)$ & $2.83(1,35.15)$ & 0.220 & $<0.0001$ & 0.0003 \\
\hline PCT $(<0.5 \mathrm{ng} / \mathrm{ml})(\mathrm{n}=39)$ & $0.05(0.05,0.16)$ & $0.05(0.05,0.35)$ & $0.05(0.05,0.1)$ & 0.639 & $<0.0001$ & $<0.0001$ \\
\hline ESR, $\mathrm{mm} / \mathrm{h}(\mathrm{n}=32)$ & $26.49 \pm 24.11$ & $34.98 \pm 69.48$ & $19.89 \pm 20.30$ & 0.083 & $>0.1$ & 0.06 \\
\hline Albumin $(\mathrm{g} / \mathrm{L})$ & $33(28,35)$ & $29(27,34)$ & $35(32,36)$ & $\mathbf{0 . 0 3 7}$ & $>0.1$ & 0.038 \\
\hline ALT $(\mathrm{IU} / \mathrm{L}), \mathrm{median}(\mathrm{IQR})$ & $22(15,45)$ & $26(17,69.5)$ & $20(15,39)$ & 0.161 & $<0.0001$ & 0.0003 \\
\hline AST(IU/L), median $(\mathrm{IQR})$ & $25(19,46)$ & $32.5(20.25,62.75)$ & $21(18,34)$ & 0.145 & $<0.0001$ & $<0.0001$ \\
\hline Blood glucose $(\mathrm{mmol} / \mathrm{L})$ & $5.56(4.62,7.29)$ & $6.62(5.43,11.05)$ & $4.7(4.22,5.67)$ & $\mathbf{0 . 0 0 1}$ & 0.0277 & $>0.1$ \\
\hline Creatinine $(\mu \mathrm{mol} / \mathrm{L})$ & $78(57.5,111)$ & $51(8.84,78.5)$ & $76.8(38.4,117)$ & 0.425 & $<0.0001$ & $<0.0001$ \\
\hline Uric acid $(\mu \mathrm{mol} / \mathrm{L})$ & $234(174.5,379.5)$ & $199.5(146.8,269.5)$ & $314(239,419)$ & $\mathbf{0 . 0 0 8}$ & $<0.0001$ & $>0.1$ \\
\hline BUN $(\mathrm{mmol} / \mathrm{L})$ & $5.4(4,8.1)$ & $5.15(3.65,6.6)$ & $5.5(4.3,9.9)$ & 0.701 & $<0.0001$ & $<0.0001$ \\
\hline Viral co-infection $(\%)$ & $3(5.7 \%)$ & 0 & $3(13 \%)$ & 0.075 & - & - \\
\hline Bacterial co-infection $(\%)$ & $3(5.7 \%)$ & $2(6.7 \%)$ & $1(4.3 \%)$ & 1 & - & - \\
\hline
\end{tabular}

$\mathrm{WBC}=$ White blood cell, $\mathrm{CRP}=\mathrm{C}$-reactive protein, $\mathrm{ESR}=$ Erythrocyte sedimentation rate, $\mathrm{ALT}=\mathrm{Alanine}$ aminotransferase, $\mathrm{AST}=\mathrm{Aspartate}$ aminotransferase, BUN=Blood urea nitrogen.

$\mathrm{P}_{\text {value }}{ }^{*}$ means the $\mathrm{p}$ value of $\mathrm{KS}$ normality test in $\mathrm{Adv}+$ pneumonia group, $\mathrm{P}$ value\# means the $\mathrm{p}$ value of KS normality test in Adv+ non-pneumonia group.

Data are shown as mean $\pm \mathrm{SD}$, median $(\mathrm{IQR})$ or number $(\%)$.

States military recruits as fever and cough [7,25]. A retrospective study involving 80 hospitalized children with adenovirus-associated pneumonia in Taiwan, conducted from 2000 to 2008, reported cough (99\%), fever (96\%), rhinorrhea (82\%), dyspnea (42\%), gastrointestinal symptoms (vomiting, diarrhea, and abdominal pain), and 
Table 4. Immune phenotype of white blood cells of patients with Adv+ pneumonia and Adv+ non-pneumonia ( $n=39)$

\begin{tabular}{|l|l|l|l|l|l|}
\hline \multirow{2}{*}{ variables } & $\begin{array}{l}\text { Adv+ pneumonia } \\
(\mathrm{n}=21)\end{array}$ & $\begin{array}{l}\text { Adv+ non-pneumonia } \\
(\mathrm{n}=16)\end{array}$ & \multirow{2}{*}{$\mathrm{p}$ value } & \multicolumn{2}{|l|}{ KS normality test } \\
\cline { 3 - 6 } & & & $\mathrm{p}$ value* & $\mathrm{p}$ value\# \\
\hline $\mathrm{CD}^{+} \mathrm{T}$ cells, cells $/ \mathrm{mm}^{3}$ & $346.5(204,1259)$ & $1851(1109,2012)$ & $<\mathbf{0 . 0 0 1}$ & 0.0091 & 0.0833 \\
\hline $\mathrm{CD}^{+} \mathrm{T}$ cells, cells $/ \mathrm{mm}^{3}$ & $217(102.2,734.8)$ & $975(604,1346)$ & $<\mathbf{0 . 0 0 1}$ & 0.0087 & $>0.1$ \\
\hline $\mathrm{CD}^{+} \mathrm{T}$ cells, cells $/ \mathrm{mm}^{3}$ & $152(64.25,403.3)$ & $570(382,764)$ & $\mathbf{0 . 0 3}$ & 0.002 & $>0.1$ \\
\hline
\end{tabular}

$\mathrm{P}_{\text {value }}$ means the $\mathrm{p}$ value of KS normality test in $\mathrm{Adv}+$ pneumonia group, $\mathrm{P}$ value\# means the $\mathrm{p}$ value of KS normality test in Adv+ non-pneumonia group.

Data are shown as median (IQR).

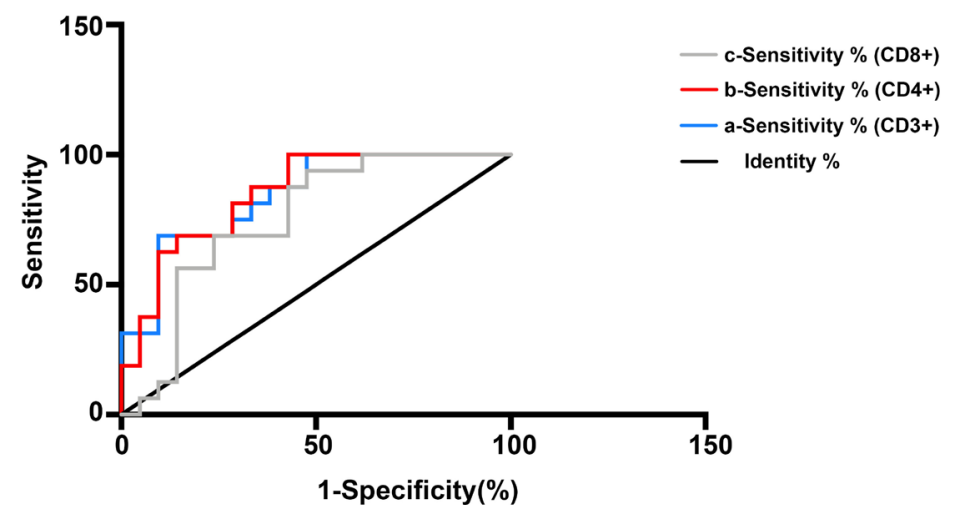

Figure 2. Receiver operating characteristic (ROC) curve of absolute number of $\mathrm{CD} 3+, \mathrm{CD} 4+, \mathrm{CD} 8+\mathrm{T}$ cells to evaluate for the presence of pneumonia in in $\mathrm{Adv}+$ patients. The areas under the ROC curve (AUC) of counts of CD3+ (a), CD4+ (b), CD8+ (c) T cells to predict severity of the disease were $0.8423,0.8482$, and 0.75 respectively.

neurological symptoms as the most common symptoms [15]. Among Korean military personnel, the most frequently observed symptoms were cough (83\%-98\%) and fever (83\%-98\%); diarrhea was seen only rarely (12\%$20 \%)[16,26]$. Moreover, reportedly, adenovirus-associated pneumonia was significantly associated with a higher risk of fever, high fever $\left(>39^{\circ} \mathrm{C}\right)$, nasal congestion, sore throat, throat clearing, headache, and pharyngeal inflammation than was adenovirus-negative pneumonia [26]. However, in the present study, Adv+ pneumonia manifested with fever (66.7\%), cough (63.3\%), and tachypnea (16.7\%), and Adv+ pneumonia was correlated with a higher risk of fever and cough and longer duration of hospitalization than was Adv+ non-pneumonia. These results were in agreement with previously published results, except for the prevalence rate of fever. This may be explained by a relatively higher incidence rate of bacterial co-infection (confirmed by PCR test and Gram staining/microbial culture) in the previous study [16] than in the current study.

A previous study revealed the WBC $(8.3 \times 1000$ cells/ $\mu \mathrm{L})$ and neutrophil counts $(6.7 \times 1000$ cells $/ \mu \mathrm{L})$ of United
States military trainees with Adv-14 pneumonia [27]. In the current study, similar results were observed in the Adv+ pneumonia group: WBC counts, $\left.7.1 \pm 3.9 \times 10^{9} / \mathrm{L}\right)$ and percentage of neutrophils $(70.66 \% \pm 13.58 \%)$; however, these data were not significantly different between patients with $\mathrm{Adv}+$ non-pneumonia and $\mathrm{Adv}+$ pneumonia. Patients with Adv+ pneumonia showed elevated CRP levels and PCT levels $<0.05 \mathrm{ng} / \mathrm{ml}$; however, 5 patients $(16.7 \%)$ showed elevated PCT levels $(>0.5 \mathrm{ng} / \mathrm{mL})$. Moreover, only 2 patients with $\mathrm{Adv}+$ pneumonia (6.7\%) showed evidence of bacterial co-infection: Klebsiella pnuemoniae and Staphylococcus aureus, respectively. The rarity of bacterial and adenovirus co-infection led us to propose the presence of AdV-associated pneumonia in our patients.

Previous studies evaluated a wide spectrum of CT images from different sample populations and found the following features in different proportions: consolidation, ground-glass opacity, pleural effusion, septal thickening, and nodules; however, till date, there is no consensus regarding the radiological manifestations of $\mathrm{Adv}+$ pneumonia. Chan et al. evaluated the CT images of 104 
immunocompetent patients with Adv+ pneumonia and reported that the most frequent pattern was consolidation with or without surrounding ground-glass opacity, with subpleural and peribronchovascular distributions [18], a pattern that was also observed in the CT images of 152 Korean military personnel with Adv (consolidation with ground-glass opacity patterns showing lobar distribution) [16]. Moreover, ground-glass opacity was observed more frequently in patients with adenovirus infection than in those with other viral and bacterial infections [28]. Patients with Adv+ pneumonia in the present study were more likely to show consolidation; however, only 8 patients $(26.7 \%)$ showed ground-glass opacities and only 5 immunocompetent patients showed the previously mentioned traits of conspicuous consolidation with surrounding ground-glass opacity. Some studies showed that unilateral involvement or single-lobe involvement was more common in patients with $\mathrm{Adv}+$ pneumonia $[18,26]$, which contradicts the finding of the present study (bilateral lesions) [29,30]. However, large-scale imaging findings on adenovirus pneumonia are necessary to confirm the CT features suggestive of this disease at the time of presentation.

Immune responses play an essential role in adenovirus infection, which may also explain why individuals with immunodeficiency are more susceptible to severe Adv+ pneumonia. Host response to adenovirus infection has been observed in humans and animal models. Adenovirus initially triggers a robust innate immune response, causing a wide spectrum of viral-induced responses via cellular pathways [31,32]. Chen et al. reported that severe Adv55 infection was significantly associated with excessive immune reactions or inflammatory responses such as increases in serum IFN- $\gamma$, IL-4, and IL-10 levels [14]. Another study involving 21 cases of adenovirus pneumonia reported relative lymphopenia [1]. A retrospective study conducted in Taiwan indicated an inhibition of cellular immunity, as evidenced by significant reduction in counts of $\mathrm{CD}^{+}, \mathrm{CD}^{+}$, and $\mathrm{CD} 20^{+} \mathrm{T}$-cells in patients with Adv7 pneumonia showing pleural effusion [17]. Toth et al. demonstrated a significant decrease in populations of $\mathrm{CD}^{+}, \mathrm{CD}^{+}$, and $\mathrm{CD} 8^{+} \mathrm{T}$-cells in the liver and spleen of Syrian primates at 1 and 7 days after intravenous injection of adenovirus [33]. Similarly, our data implied greater cellular immunosuppression in patients with $\mathrm{Adv}+$ pneumonia, as demonstrated by a decline in counts of $\mathrm{CD}^{+}, \mathrm{CD}^{+}$, and $\mathrm{CD} 8^{+} \mathrm{T}$-cells, than in patients with $\mathrm{Adv}+$ non-pneumonia. Even though further analysis of the ROC curve suggested that counts of $\mathrm{CD}^{+}, \mathrm{CD}^{+}$, and $\mathrm{CD} 8^{+}$ T-cells may be used as predictors of pneumonia in Adv+ patients when combined with CT findings and clinical symptoms, the results should be interpreted with caution and need further research in the light of many factors that may contribute to this condition.

There are some limitations in present study that warrant mentioning. Firstly, the small sample size of this study precluded our ability to further subgroup analysis. For instance, in a large-scale study, the comparisons of clinical and radiological features between immunosuppressed and immunocompetent patients with $\mathrm{Adv}+$ pneumonia or $\mathrm{Adv}+$ non-pneumonia could shed light upon some clinical implications toward understanding the pathogenesis of the disease. Secondly, the retrospective search excluded some $\mathrm{AdV}+$ patients in our study, as PCR tests for respiratory viruses was not routinely performed on all patients. This is also a bias towards eligible cases in this study. Lastly, in our setting, we did not determine the adenovirus serotypes, which may provide some clues in the observed differences of clinical and imaging findings between patients with $\mathrm{Adv}+$ pneumonia and Adv+ non-pneumonia. Moreover, clinical presentation, severity and outcomes may vary from AdV types.

In conclusion, our data showed that the frequently observed symptoms of Adv+ pneumonia are cough and fever, and that the most common image findings were consolidation; however, these results were not specific for Adv+ pneumonia. We also demonstrated that cellular immunity is compromised in patients with $\mathrm{Adv}+$ pneumonia.

\section{Funding}

Study design was supported by Grant 81770025 from National Natural Science Foundation of China, Collection, analysis and interpretation of data were supported by Grant ZH2018QNA48 from Cross research funds of Translational Medicine and Grant 2017ZZ02014 from Shanghai key discipline for respiratory diseases.

\section{Availability of data and materials}

All data generated or analyzed during this study are included in this published article.

\section{Author's contribution}

Guochao Shi was responsible for the conceptualization, funding acquisition, they also revised the manuscript. Chunrong Huang and Dong Wei collected the data, analyzed the data and drafted the manuscript. Yahui Liu validated and supervised the project.

\section{Ethics approval and consent to participate}

The study was approved by the Ethics Committee of Ruijin Hospital, Shanghai Jiao Tong University School of Medicine, due to the retrospective nature of the study, informed consent was waived. 


\section{References}

1. Clark TW, Fleet DH, Wiselka MJ. Severe community-acquired adenovirus pneumonia in an immunocompetent 44 -year-old woman: a case report and review of the literature. Journal of Medical Case Reports 2011; 5: 259. doi: 10.1186/1752-1947-5259

2. Yu HX, Zhao MM, Pu ZH, Wang YQ, Liu Y. Clinical data analysis of 19 cases of community-acquired adenovirus pneumonia in immunocompetent adults. International Journal of Clinical and Experimental Medicine 2015; 8 (10): 1905119057

3. Chakrabarti S, Mautner V, Osman H, Collingham KE, Fegan $\mathrm{CD}$ et al. Adenovirus infections following allogeneic stem cell transplantation: incidence and outcome in relation to graft manipulation, immunosuppression, and immune recovery. Blood 2002; 100 (5): 1619-1627. doi: 10.1182/ blood-2002-02-0377

4. Tang L, Wang L, Tan X, Xu W. Adenovirus serotype 7 associated with a severe lower respiratory tract disease outbreak in infants in Shaanxi Province, China. Virology Journal 2011; 8: 23. doi: 10.1186/1743-422X-8-23

5. Heo JY, Lee JE, Kim HK, Choe KW. Acute lower respiratory tract infections in soldiers, South Korea, April 2011-March 2012. Emerging Infectious Diseases 2014; 20 (5): 875-877. doi: 10.3201/eid2005.131692

6. Gray GC, Goswami PR, Malasig MD, Hawksworth AW, Trump DH et al. Adult adenovirus infections: loss of orphaned vaccines precipitates military respiratory disease epidemics. For the Adenovirus Surveillance Group. Clinical Infectious Disease 2000; 31 (3): 663-670. doi: 10.1086/313999

7. ussell KL, Hawksworth AW, Ryan MA, Strickler J, Irvine M et al. Vaccine-preventable adenoviral respiratory illness in US military recruits, 1999-2004. Vaccine 2006; 24 (15): 2835-2842. doi: 10.1016/j.vaccine.2005.12.062

8. Cheng Z, Yan Y, Jing S, Li WG, Chen WW et al. Comparative Genomic Analysis of Re-emergent Human Adenovirus Type 55 Pathogens Associated With Adult Severe CommunityAcquired Pneumonia Reveals Conserved Genomes and Capsid Proteins. Frontiers in Microbiology 2018; 9: 1180. doi: 10.3389/ fmicb.2018.01180

9. Zhao S, Wan C, Ke C, Seto J, Dehghan S et al. Re-emergent human adenovirus genome type $7 \mathrm{~d}$ caused an acute respiratory disease outbreak in Southern China after a twenty-one year absence. Scientific Reports 2014; 4: 7365. doi: 10.1038/ srep07365

10. Kajon AE, Lu X, Erdman DD, Louie J, Schnurr D et al. Molecular epidemiology and brief history of emerging adenovirus 14-associated respiratory disease in the United States. The Journal of Infectious Diseases 2010; 202 (1): 93-103. doi: $10.1086 / 653083$

11. Zhang Q, Seto D, Cao B, Zhao S, Wan C. Genome sequence of human adenovirus type 55, a re-emergent acute respiratory disease pathogen in China. Journal of Virology. 2012; 86 (22): 12441-12442. doi: 10.1128/JVI.02225-12
12. Lai CY, Lee CJ, Lu CY, Lee PI, Shao PL et al. Taiwan Pediatric Infectious Disease, Adenovirus serotype 3 and 7 infection with acute respiratory failure in children in Taiwan, 2010-2011, PLoS One 2013; 8 (1): e53614. doi: 10.1371/journal.pone.0053614

13. Erdman DD, Xu W, Gerber SI, Gray GC, Schnurr D et al. Molecular epidemiology of adenovirus type 7 in the United States, 1966-2000. Emerging Infectious Diseases 2002; 8 (3): 269-277. doi: 10.3201/eid0803.010190

14. Chen WW, Nie WM, Xu W, Xie YX, Tu B et al. Cross-sectional study of the relationship of peripheral blood cell profiles with severity of infection by adenovirus type 55. BMC Infectious Diseases 2014; 14: 147. doi: 10.1186/1471-2334-14-147

15. Chen SP, Huang YC, Chiu CH, Wong KS, Huang YL et al. Clinical features of radiologically confirmed pneumonia due to adenovirus in children. Journal of Clinical Virology 2013; 56 (1): 7-12. doi: 10.1016/j.jcv.2012.08.021

16. Yoon H, Jhun BW, Kim H, Yoo H, Park SB. Characteristics of Adenovirus Pneumonia in Korean Military Personnel, 20122016. Journal of Korean Medical Science 2017; 32 (2): 287-295. doi: $10.3346 / \mathrm{jkms.2017.32.2.287}$

17. Shen CF, Wang SM, Ho TS, Liu CC. Clinical features of community acquired adenovirus pneumonia during the 2011 community outbreak in Southern Taiwan: role of host immune response. BMC Infectious Diseases 2017; 17 (1): 196. doi: 10.1186/s12879-017-2272-5

18. Park CK, Kwon H, Park JY. Thin-section computed tomography findings in 104 immunocompetent patients with adenovirus pneumonia, Acta Radiologica 2017; 58 (8): 937-943. doi: 10.1177/0284185116681039

19. Ewig S, Ruiz M, Mensa J, Marcos MA, Martinez JA et al. Severe community-acquired pneumonia. Assessment of severity criteria. American Journal of Respiratory and Crittical Care Medicine 1998; 158 (4): 1102-1108. doi: 10.1164/ ajrccm.158.4.9803114

20. Mandell LA, Wunderink RG, Anzueto A, Bartlett JG, Campbell GD et al. Infectious Diseases Society of America/American Thoracic Society consensus guidelines on the management of community-acquired pneumonia in adults. Clinical Infectious Diseases 2007; 44 Suppl 2: S27-72. doi: 10.1086/511159

21. Livak KJ, Schmittgen TD. Analysis of relative gene expression data using real-time quantitative PCR and the 2(-Delta Delta C(T)) Method. Methods 2001; 25 (4): 402-408. doi: 10.1006/ meth.2001.1262

22. Dingle JH, Langmuir ad. Epidemiology of acute, respiratory disease in military recruits. American Review of Respiratory Disease 1968; 97 (6): Suppl:1-65. doi: 10.1164/arrd.1968.97.1.1

23. Khanal S, Ghimire P, Dhamoon AS. The Repertoire of Adenovirus in Human Disease: The Innocuous to the Deadly. Biomedicines 2018; 6 (1). doi: 10.3390/biomedicines 6010030

24. Lion T. Adenovirus infections in immunocompetent and immunocompromised patients. Clinical Microbiology Reviews 2014; 27 (3): 441-462. doi: 10.1128/CMR.00116-13 
25. Brosch L, Tchandja J, Marconi V, Rasnake M, Prakash V et al. Adenovirus serotype 14 pneumonia at a basic military training site in the United States, spring 2007: a case series. Millitary Medicine 2009; 174 (12): 1295-1299. doi: 10.7205/ milmed-d-03-0208

26. Park JY, Kim BJ, Lee EJ, Park KS, Park HS et al. Clinical Features and Courses of Adenovirus Pneumonia in Healthy Young Adults during an Outbreak among Korean Military Personnel. PLoS One 2017; 12 (1): e0170592. doi: 10.1371/ journal.pone.0170592

27. Vento TJ, Prakash V, Murray CK, Brosch LC, Tchandja JB et al. Pneumonia in military trainees: a comparison study based on adenovirus serotype 14 infection. Journal of infectious Diseases 2011; 203 (10): 1388-1395. doi: 10.1093/infdis/jir040

28. Miller WT, Jr., Mickus TJ, Barbosa E, Jr., Mullin C, Van Deerlin $\mathrm{VM}$ et al. CT of viral lower respiratory tract infections in adults: comparison among viral organisms and between viral and bacterial infections. AJR American Journal Roentgenology 2011; 197 (5): 1088-1095. doi: 10.2214/AJR.11.6501

29. Chong S, Lee KS, Kim TS, Chung MJ, Chung MP et al. Adenovirus pneumonia in adults: radiographic and highresolution CT findings in five patients. AJR American Journal Roentgenology 2006; 186 (5): 1288-1293. doi: 10.2214/ AJR.05.0128
30. Narra R, Bono P, Zoccoli A, Orlandi A, Piconi S et al. Acute respiratory distress syndrome in adenovirus type 4 pneumonia: A case report. Journal of Clinical Virology 2016; 81: 78-81. doi: 10.1016/j.jcv.2016.06.005

31. Hartman ZC, Kiang A, Everett RS, Serra D, Yang XY et al. Adenovirus infection triggers a rapid, MyD88-regulated transcriptome response critical to acute-phase and adaptive immune responses in vivo. Journal of Virology 2007; 81 (4): 1796-1812. doi: 10.1128/JVI.01936-06

32. Cook J, Radke J. Mechanisms of pathogenesis of emerging adenoviruses. F1000Research 2017; 6: 90. doi: 10.12688/ f1000research.10152.1

33. Toth K, Lee SR, Ying B, Spencer JF, Tollefson AE et al. STAT2 Knockout Syrian Hamsters Support Enhanced Replication and Pathogenicity of Human Adenovirus, Revealing an Important Role of Type I Interferon Response in Viral Control. PLoS Pathogens 2015; 11 (8): e1005084. doi: 10.1371/journal. ppat. 1005084 